\title{
Epistemologiczny charakter logiki buddyjskiej
}

\section{The epistemological character of Buddhist logic}

\author{
Michal Lipnicki \\ Instytut Językoznawstwa \\ Uniwersytet im. Adama Mickiewicza \\ al. Niepodległości 4, 61-874 Poznań
}

\begin{abstract}
The article explores the relation between epistemology and the logical concepts developed by Buddhists. In the Indian philosophy logic is conceived as the theory of valid knowledge and its specific shape is determined by the character of epistemological conceptions. We are concentrated on the ideas developed in VI and VII centuries by the philosophers from the vijũannavãda sect. Though references to some theories of other Buddhist sects are inevitable.
\end{abstract}

\section{Wprowadzenie}

Na poczatku niniejszego artykułu należy określić, aby uniknać kontrowersji, jakiego typu zagadnienia zalicza się do obszaru zainteresowania logiki indyjskiej. W dużej mierze są to problemy, jakimi aktualnie zajmuje się pragmatyka logiczna - ustalanie schematów wnioskowań i formulowanie zasad ich poprawności, opis regul prowadzenia uczciwej debaty filozoficznej oraz opisywanie nieuczciwych chwytów sofistycznych (-Matilal 1998: 1). Warto zauważyć, że byly one rozpatrywane w obrębie dziedziny badającej znacznie szerszą problematykę i posiadają raczej „przednaukowy" charakter. 
Refleksja logiczna w Indiach byla częścią teorii poznania, stąd niesposób opisywać zagadnień $\mathrm{z}$ nia związanych $\mathrm{w}$ oderwaniu od szerszego kontekstu epistemologicznego. Poza tematami wymienionymi powyżej w traktatach logiczno-epistemologicznych podejmowano takie zagadnienia, jak: semantyka, teoria doznawania bodźców, możliwość poznania rzeczywistości oraz adekwatność naszej wiedzy o niej. Uznawanie epistemologicznego charakteru logiki jest wspólne wszystkim indyjskim szkołom filozoficznym. Wnioskowanie, tak jak percepcja, jest kryterium poznawczym i źródlem wiedzy. Dlatego też, badając logikę indyjską, należy mieć na uwadze fakt, że kategorie i koncepcje logiczne rozpatrywane sajako fenomeny psychiczne, od których zależny jest ksztalt konstruowanych na ich podstawie sądów oraz specyficzne i ściśle określone struktury schematów wnioskowania. Ponadto logika indyjska przez caly okres swojego rozwoju posiadala charakter pragmatyczny - miała slużyć jako narzędzie do wykorzystania w debacie. Funkcja, jaka pelnily schematy wnioskowania, nie było tylko weryfikowanie wartości poznania, lecz również przekonanie adwersarza do uznania stawianej tezy. Stąd traktaty, podejmujące tematykę logiczna, obfitują w listy różnego typy „chwytów sofistycznych". Mając na uwadze wlaśnie taki charakter logiki w Indiach, niezwykle istotne przy próbach interpretacji jest oddanie jej związku z epistemologią. Tylko w taki sposób możliwy jest jej adekwatny opis, w którym oddany zostałby jej unikalny charakter. Celem niniejszego artykulu jest opisanie owych relacji na przykładzie specyficznego fragmentu logiki indyjskiej, jakim jest logika buddyjska. Termin ten odnosi się zarówno do koncepcji logicznych rozwijanych przez filozofów buddyjskich, jak i okresu, w którym pomysły buddystów były dominujące $w$ indyjskich dyskusjach logicznych. Czasy te przypadają na VI-VII w. n.e. i wiążą się z pracami dwóch wielkich filozofów - mistrzów Dignāga i Dharmakirti (Stcherbatsky 1962: 1). Prace tych uczonych zalicza się do szkoły vijnñānavāda, nurtu māhayāna. 


\section{Kryteria poznawcze (pramāña)}

Kryteria poznawcze to „procedury” (procesy psychiczne), za pomoca których zachodzi poznanie. Buddyści wyróżniali ich dwa rodzaje: bezpośrednie - percepcję (pratyaksa) i pośrednie - wnioskowanie (anumāna). Obiektami percepcji sa realne ${ }^{1}$, istniejące obiektywnie byty jednostkowe, $\mathrm{z}$ kolei obiektami wnioskowania sa konstrukcje umyslowe będace uogólnionymi koncepcjami lub obrazami bytów jednostkowych. Takie podejście do zagadnienia przedmiotów poznania wpisuje się w pogląd filozoficzny zwany realizmem transcendentalnym, zgodnie z którym obiekty istniejące realnie są dostępne poznaniu (Ajdukiewicz 2003: 54). Nie jest możliwe, aby za pośrednictwem danego kryterium, pośredniego lub bezpośredniego, poznać byty, które sa obiektami poznawanymi poprzez drugie kryterium. Ze względu na taki podzial poznawanych obiektów, buddyści podają dwa typy wiedzy, mianowicie: wiedzę będącą efektem aktu percepcji - niekonceptualną, oraz wiedzę wynikajaca $\mathrm{z}$ wnioskowania, majaca charakter konceptualny (Bhatt, Mehrotra 2000: 22). Owe rozróżnienie na wiedzę konceptualną, zależną od języka i w języku wyrażalną oraz wiedzę niekonceptualna, będaca „,czystym doznaniem" niewyrażalnym w języku, ma dosyć dhuga tradycję w buddyzmie. W należącym do palijskiego kanonu dziel sekty theravāda, zbiorze sutr Majjhimanikāya znajduje się tekst przypisywany Buddzie - Cülavedallasuttam, w którym czytamy:

„Trzy są [rodzaje] procesów: procesy cielesne, procesy jezykowe, procesy mentalne.

Które tedy są procesy cielesne, które - językowe, które - mentalne?

Pojęcia realności ontologicznej w buddyzmie nie należy utożsamiać z realnym istnieniem bytów jako takich. Sprowadza się ono raczej do uznania obiektywności („dziania się") manifestacji danego bytu, które dla niewprawnego oka błędnie rysują się jako trwały obiekt, posiadający swoją istotę. Z takiego wlaśnie poglądu na rzeczywistość wynikaja niezwykle liczne paradoksalne stwierdzenia, jak np. „rzecz nie jest rzecza” (por. Przybysławski 2009). 
Wdychanie i wydychanie to procesy cielesne, rozumowanie i rozważanie to procesy językowe, postrzeganie i odczuwanie to procesy mentalne." (Kania 2007: 159).

W cytacie tym wyraźnie oddzielone są od siebie rozumowanie i percepcja. Język jest konceptualny z samej swojej natury i jak widać, jest charakterystyczny tylko dla procesów rozumowania. $Z$ kolei percepcja odpowiadająca w przedstawionym tekście postrzeganiu jest procesem czysto mentalnym, odbywającym się z wylączeniem języka.

Buddyści, postulowali równoważność kryteriów poznawczych (pramāna) i samego aktu poznania (jñāna). Poznanie wg nich powstaje, zawierając w sobie formę obiektu poznawanego, jak i sam akt poznania (Bhatt, Mehrotra, 2000: 14). Nie chodzi tutaj o to, że proces psychiczny - poznanie, przyjmuje taką wlaśnie formę. Istotą tego stwierdzenia jest to, że każde poznanie w sposób konieczny odnosi się do swojego obiektu, dodatkowo prawdziwe poznanie odnosi się do obiektu „takiego, jakim on jest”. Tylko w taki sposób można powiedzieć, że „przyjmuje formę obiektu” - odzwierciedla w umyśle jego postać. Jak już wspomniano - kryterium prawdziwości poznania uzależnione jest od jego odniesienia do tego obiektu. Efektem prawdziwego poznania jest prawdziwa wiedza, natomiast wiedza jest prawdziwa, jeżeli poprawnie odwzorowuje swój obiekt.

\section{Percepcja (pratyaksa)}

Oto jak percepcję definiowal jeden z czolowych przedstawicieli szkoly vijñānavāda - Vasubhandhu: ,Percepcja jest to poznanie będqce produktem jej przedmiotu." (Bhatt, Mehrotra 2000: 26). Definicja ta jest bardzo nieostra i trudno najej podstawie powiedzieć coś więcej o percepcji niż to, że jest ona zdeterminowana przez swój przedmiot, którym jest obiektywnie istniejący byt. Żaden umyslowy obiekt konceptualny tą droga poznany być nie może. Buddyści uważają zatem, że w obrębie percepcji nie może mieć miejsca myślenie konceptualne, ergo percepcja nie jest wyrażalna w języku, stanowi „czyste doznanie przedmiotu”. 
W latach późniejszych uczeń Vasubhandhu - Dignāga² rozwinąl definicję swojego mistrza. Wyraźnie oddzielił percepcję od wnioskowania, charakteryzując ją jako negatywny odpowiednik tegoż (Bhatt, Mehrotra 2000: 27). Rozdzielenia dokonal na poziomie konceptualizacji, charakteryzując percepcję jako poznanie niekonceptualne, podczas gdy wnioskowanie ma charakter konceptualny. Percepcja nie jest jednak wyłącznie postrzeżeniem danego bytu, kontaktem narzadu zmyshu ze swoim obiektem. Etap ten jest jedynie pierwszym stadium percepcji, dalsze jej stadia sąjuż czymś więcej, chociaż ciagle zachowuja niekonceptualny charakter.

Wielki kontynuator myśli mędrca Dignāga-Dharmakirti, do warunku o niekonceptualnym charakterze percepcji dodal kolejny - bycie niewadliwym (abhrōntam). Tym samym percepcję charakteryzowano jako poznanie niekonceptualne i niewadliwe. Jest to poznanie obiektu w jego charakterystycznym kształcie, odróżniajacym go od innych rzeczy, tak homogenicznych, jak i heterogenicznych. Taka percepcja jest „,czystym doświadczeniem”, a jej obiektem są przedmioty realne (Bhatt, Mehrotra 2000: 30). Na poziomie percepcji nie może mieć miejsca nazywanie, ponieważ jest to proces werbalny, a co za tym idzie również konceptualny, a tego czynnika w wyżej wymienionym kryterium poznawczym brakuje. Obiekt postrzegany jest doświadczany, lecz nie następuje żadne skojarzenie z nazwa go denotujaca. Dzieje się tak dlatego, że percepcja zdeterminowana jest przez swój obiekt, a jej efektem jest poznanie mające formę tego wlaśnie obiektu, a nie wyrażenia językowego. Jednocześnie wyraz nie jest ani obecny w tym obiekcie, ani nie jest $z$ nim identyczny. A zatem ów obraz nie może zostać skojarzony $z$ odpowiednią ekspresją werbalną bez odwoływania się do innych funkcji umyshu niż ta odpowiedzialna za postrzeganie. Dopiero wiedza konceptualna niebędąca już percepcją przedstawia obiekt percepcji wraz z wyrazem go denotującym ${ }^{3}$.

2 Bocheński w swoim opus magnum - A History of Formal Logic, w rozdziale poświęconym logice indyjskiej określil go mianem ,najwybitniejszego logika indyjskiego" (Bocheński 2001: 118)

3 Na podstawie refleksji nad poznaniem konceptualnym i niekonceptualnym dochodzi Dharmakirti do ciekawej koncepcji języka zewnętrznego i wewnętrznego. Wskazuje on na dwa sposoby werbalizacji. Pierwszy to werbalizacja 


\section{Wnioskowanie (anumāna)}

Buddyści uznają procesualną naturę rzeczywistości. Oznacza to, że prawdziwa natura obiektów takiej rzeczywistości jest dyskretna. Każdy element istnieje tylko przez moment, po czym przemija i daje początek następnej reprezentacji o tej samej formie, będącej już jednak innym bytem ${ }^{4}$. Takie chwilowo manifestujące się obiekty sa postrzegane droga percepcji - ,czystego doznania”. Skoro każda taka manifestacja jest bytem odrebnym od swojego poprzednika, to każdy obiekt postrzegany jest innym obiektem, a co za tym idzie, powinien posiadać inną nazwę niż poprzednik. Oczywiście tak się nie dzieje, ponieważ prowadziloby to do ekspansji słownika danego języka do wprost niewyobrażalnych rozmiarów, w którym każde słowo mogloby być użyte tylko raz. Pelne doświadczenie takiej rzeczywistości jest jednym z celów praktyki medytacyjnej, jak i niezwykle ważnym punktem na drodze do oświecenia. Jednakże dla celów praktycznych przyjmowana jest druga, pomocnicza wizja rzeczywistości. W niej wszelkie substancje, wlasności czy też ruch sa ujęte w języku, ustabilizowane w nazwach i w związku z tym traktowane jako istniejące realnie i niepodlegające permanentnej zmianie. Taka rzeczywistość pomocnicza funkcjonuje niczym filtr nakladany na wlaściwą rzeczywistość i to jej obiektami wg buddystów zajmuje

potencjalna, drugi to werbalizacja rzeczywista. Werbalizacja potencjalna odbywa się tylko na poziomie mentalnym, gdzie każdy koncept otrzymuje swoją potencjalną formę językową. Na poziomie werbalizacji rzeczywistej dochodzi do faktycznej realizacji wypowiedzi zaplanowanej na poziomie potencjalnym.

4 Prawo permanentnej zmienności i nietrwałości bytu jest fundamentalnym zalożeniem buddyzmu. Co ciekawe, ponad dwa tysiace lat po ogloszeniu go przez Buddę, wspólczesna fizyka teoretyczna doszła do podobnych wniosków. W teorii względności odchodzi się od "tradycyjnego" rozumienia materii jako "trwającej caly czas i nigdy niebędacej w więcej niż jednym miejscu na raz." (B. Russell 2000: 162.) Oto, jaki charakter nadaje się materii w ramach teorii relatywistycznej: „Tego rodzaju składnikami jest to, co nazywamy „zdarzeniami". Zdarzenie nie jest czymś, co stale trwa, lecz tylko zmienia miejsce, jak to jest $\mathrm{z}$ tradycyjna porcją materii. Zdarzenie istnieje jedynie przez dana mu krótką chwilę i znika. Porcja materii zmienia się więc w ciąg zdarzeń." (B. Russell 2000: 162f.). 
się logika (Stcherbatsky 1962: 2). Dlatego też istota kluczowego pojęcia logiki indyjskiej - anumâna, oznaczajacego wnioskowanie, jest wyraźnie zależna od języka, a tym samym zdecydowanie odmienna od percepcji, chociaż wtórna w stosunku do niej.

W epistemologii buddyjskiej mianem wnioskowania (anumāna) określano proces mentalny prowadzący do zdobycia określonej wiedzy, jak i wiedzę tą drogą uzyskaną. Dignāga uważal wnioskowanie za werbalizowalny proces mentalny. Możliwość zwerbalizowania nie powoduje, że każdy taki proces musi być koniecznie wypowiedziany w formie zdań. W przypadku, gdy pozostaje on na poziomie umyslowym, mamy do czynienia z wnioskowaniem przeprowadzanym dla samego siebie (svārthānumāna). Kiedy formuly z poziomu mentalnego przyjmują formę wypowiadanych zdań danego języka, to takie wnioskowanie nazywa się wnioskowaniem dla drugiej osoby (prārthānumāna) i może posłużyć jako narzędzie do użycia w debacie filozoficznej lub jako dowód stawianej tezy w zwykłej rozmowie.

Aby wnioskowanie prārthānumãna było skuteczne, tzn. skłoniło rozmówcę do uznania tezy, musi odzwierciedlać swoim ksztaltem wnioskowanie z poziomu psychicznego svârthānumāna. Poznanie wynikające $z$ wnioskowania ma formę sądu. Zahóżmy, że obserwujemy dym unoszacy się ze wzgórza. Dym w momencie, gdy staje się obiektem percepcji, staje się również przyczyną określonego doświadczenia, którego następstwem jest sąd postaci tam na górze jest dym. Ów sąd wynikający z percepcji w polączeniu ze wcześniej posiadaną wiedza, na podstawie której formulowane jest prawo uniwersalne mówiące, że wszystko, co dymi, to plonie, są przyczyna powstania kolejnego sądu będącego wynikiem wnioskowania - na górze jest ogień. Obiektem sądu nie jest konkretny ogień, tylko ogień funkcjonujacy jako termin uniwersalny, a powstaly w wyniku generalizacji bytów jednostkowych. Uniwersalia nie istnieją realnie, są to tylko konstrukcje logiczne wyprodukowane przez nasz umysl (Bhatt, A. Mehrotra 2000: 63).

Przedstawiony powyżej proces, na poziomie prārthānumāna posiada ściśle określoną trzystopniową strukturę i przedstawia się go jako schemat następujacej postaci: 
(i)

teza (pratijñ̄ā): na górze jest ogień;

(ii) racja (hetu): ponieważ na górze jest dym;

(iii) przyklad (udāharana, drștāinta):

przyklad pozytywny (sapaksa) - wszędzie tam, gdzie jest dym - jak wskazuje doświadczenie - jest też ogień, tak jak w kuchni; przyklad negatywny (vipaksa) - tam, gdzie nie ma ognia - jak wskazuje doświadczenie - nie ma też dymu, tak jak w jeziorzes.

$\mathrm{Na}$ ów schemat składaja się elementy, które muszą pozostawać ze sobą w ścislej relacji, aby wnioskowanie można bylo uznać za poprawne. Elementami tymi sa:

a. wlasność do udowodnienia $($ sādhya $)-$ ogień $^{6}$,

b. lokacja (paksa) - góra,

c. racja (hetu) - dym?

Oto jak pierwszy krok schematu zostal scharakteryzowany w dziele Nyâya-praveśa, napisanym przez mnicha Śankarasvāmin:

„Spośród owych [trzech elementów dowodu], teza to dobrze znane substratum, odnośnie którego sam mówca zamierza

5 Prezentowany w niniejszym artykule trójelementowy schemat jest modyfikacją wcześniejszego, pięcioelementowego schematu zaprezentowanego w należącym do nurtu ortodoksyjnej szkoły Nyẫya-vaiśesika dziele Nyẫya-sūtra autorstwa mistrza Aksapāda Gautama. Vātsyāyana Pakșilasvāmin w swoim komentarzu do tego dzieła podaje następujący przebieg wnioskowania wg tego schematu: (i) teza - tam na górze jest ogień; (ii) racja-ponieważ tam na górze jest dym-a jak wskazuje doświadczenie -wszędzie tam, gdzie jest dym, jest też ogień; (iii) przykład pozytywny - tak jak w kuchni, przykład negatywny - nie tak jak w jeziorze; (iv) zastosowanie - (a) pozytywne: w kuchni, jak w innych tego typu miejscach, gdzie można stwierdzić obecność dymu, można też stwierdzić obecność ognia, tak też na tej górze jest dym, (b) negatywne: w jeziorze, jak i innych tego typu miejscach - jak wskazuje doświadczenie - nie można stwierdzić obecności dymu, tym samym nie można stwierdzić obecności ognia. Na tej górze jednak stwierdzono obecność dymu; (v) konkluzja-wszędzie tam gdzie jest dym, jest też ogień. Na tej górze jest dym, zatem jest też ogień (por. Balcerowicz 2003: 247ff.).

6 W rzeczywistości bardziej adekwatne byłoby nadanie terminowi stanowiącemu sādhya formę „posiadanie ognia”. Ogień funkcjonuje tutaj jako wlasność orzekajaca o górze, która jest dla niej lokacja.

${ }^{7}$ Tak jak w przypadku terminu sādhya, hetu należy do kategorii własności ulokowanych w paksa. 
udowodnić, że nacechowane jest ono dobrze znany m oznacznikiem [sādhya]. Następujące uzupełnienie [powyższej] wypowiedzi [jest zrozumiale samo przez się: podmiot (teza) dowodu] nie [może być] sprzeczny (-a) z percepcją i inny mi [uznanymi kryteriami]." "S (Śankarasvâmin 1995: 40)

Na tezę składają się dwie kategorie syntaktyczne. Pierwsza z nich to lokacja ( $p a k s ̧ a$ ), która sama nie bierze bezpośredniego udzialu we wnioskowaniu, a stanowi jego tlo, określa miejsce, w którym obiekty wnioskowania się znajdują. Drugą kategorią pojawiająca się w tym kroku jest wlasność do udowodnienia ( $s \bar{a} d h y a)$, której potencjalne ulokowanie ${ }^{9} \mathrm{w}$ danej lokacji jest obiektem wnioskowania. Ponadto Śàkkarasvāmin wskazuje, że relacja między lokacją i własnością do udowodnienia jest ściśle zależna od percepcji i musi być z nią zgodna. Fakt ten można potraktować jako wskaźnik uznawania przez buddystów poznania opierającego się na percepcji za bardziej wartościowe i pewniejsze niż poznanie będące efektem wnioskowania.

Krok trzeci - przyklad ma na celu unaocznienie adwersarzowi relacji między tezą a racja zgeneralizowaną w prawie uniwersalnym „wszędzie tam, gdzie jest dym - jak wskazuje doświadczenie - jest też ogień". Albowiem nie musi ono być znane osobie, dla której taki dowód jest prowadzony. Mówca co prawda zna związek między tezą a racja, nie jest to jednak wiedza aprioryczna dostępna wszystkim ludziom. W związku z tym należy ją unaocznić rozmówcy.

Obiektem wnioskowania nie sa istniejace obiektywnie przedmioty rzeczywiste, jak w przypadku percepcji, ale uogólnione koncepty lub obrazy bytów jednostkowych będące tworami umyslo-

8 Sánkarasvāmin wykorzystuje odmienną od tej prezentowanej w niniejszej pracy egzemplifikację kolejnych stopni. W Nyāya-praveśa obiektem wnioskowania jest nietrwałość dźwięku.

9 Użyty przez autora termin „ulokowanie” jest odpowiednikiem „orzekania”. $Z$ tạ różnica, że nie oznacza on relacji między jednostkami leksykalnymi, tylko między obiektami materialnymi a własnościami. Jeżeli własność (którą w ontologii indyjskiej może być również obiekt materialny) jest ulokowana w danej lokacji, to na poziomie językowym można za pomocą terminu tę własność denotującego orzec o tej lokacji. 
wymi. Weryfikacja poprawności wnioskowania odbywa się poprzez zwerbalizowanie procesu psychicznego w postaci prezentowanego wyżej schematu. Aby wnioskowanie było poprawne, musi istnieć określona relacja między racją (hetu) a lokacją (paksa) oraz obiektami stanowiącymi przyklad pozytywny (sapaksa) i negatywny (vipaksa). Sformulowanie trzech warunków określających charakter tych relacji jest kolejną zashuga mistrza Dignāga. Zasada ta, zwana trairüpya, podaje charakter, jaki musi mieć hetu, aby bylo racja dla obiektu wnioskowania.

1. Racja powinna być obecna w miejscu, w którym ma być również obecna wlasność do udowodnienia. Na mocy tego warunku dym będzie racją dla ognia tylko wtedy, jeżeli jest obserwowany w tym samym miejscu (lokacji), w której postuluje się obecność ognia.

2. Racja musi być również obecna w homogenicznych lokacjach. Jeżeli stwierdzone zostalo, że warunek pierwszy jest spelniony, to teraz należy wykazać, że we wszystkich lokacjach, w których stwierdza się obecność dymu, stwierdza się też obecność ognia. W kuchni, gdzie wielokrotnie widziano dym, za każdym razem obecny byl też ogień.

3. Racja musi być nieobecna we wszystkich bytach heterogenicznych z paksa.

Dwa wcześniejsze kroki są niewystarczające, aby wykazać zasadność postulowanej racji. Aby byla ona adekwatna, należy jeszcze wykluczyć możliwość istnienia miejsca, w którym stwierdza się obecność dymu bez obecności ognia. Miejscem, w którym nigdy nie stwierdzono obecności ognia, jest jezioro, dlatego też nigdy nie widziano tam dymu. (Matilal 1998: 91f.).

Dwa ostatnie warunki zawarte sa implicite w trzecim kroku schematu. Warunek pierwszy jest wyrażany w kroku drugim. Niezwykle istotną kwestią, jaką ustanawia zasada trairūpya, jest relacja lącząca hetu i sādhya-zwana relacją nieodstępowania (vyāpti, ang. necessary concomitance). Aby hetu moglo być racja dla sādhya, muszą być tą relacja polączone. W Pramāna-samuccaya Dignāga charakteryzuje vyāpti jako relację lączącą dwa byty $A$ i $B$ w taki sposób, że uprawnione jest traktowanie $A$ jako znaku (linga) wska- 
zującego na istnienie zjawiska $B$. Można zatem wnioskować o $B$ na podstawie $A$ (Matilal 1998: 11).

Wnioskowanie odbywa się tylko na poziomie konceptualnym. Aby proces wnioskowania mógl zajść, musi istnieć relacja między dwoma konceptami, tak żeby następnik tej relacji był efektem zaistnienia poprzednika. Wynika z tego, że wiedza pochodząca $z$ wnioskowania jest następstwem innej, już posiadanej wiedzy. Aby taka relacja mogła mieć miejsce, pierwotna wiedza poprzedzajaca (ang. antecedent) musi mieć formę znaku (linga) wskazującego na wtórna wiedzę następująca po niej (ang. consequent). Znak taki definiuje się jako konieczny wskaźnik rzeczy innej niż on sam (lingin) (Matilal 1998: 57). Relacja między linga a lingin mówi nam, że ilekroć pojawia się jej poprzednik, pojawia się też następnik, co odpowiada sformulowanemu pojęciu relacji nieodstępowania (vyāpti). Wiedza zdobyta droga wnioskowania to wiedza o jakimś bycie na podstawie znaku, który jest z nim w relacji nieodstępowania. Jest to zatem poznanie relacyjne, którego obiekt nie jest dany bezpośrednio, zachodzi ono dopiero na mocy określonej relacji lączącej go z innym bytem. Ujmując rzecz prościej - wnioskuje się o bytach, których nie można percypować. Obiektem wnioskowania w ujęciu buddyjskim nie jest sama sādhya, lecz paksa, kwalifikowana przez sādhya ${ }^{10}$. Proces my-

10 Poniżej przedstawiona jest argumentacja na rzecz wlaśnie takiego ksztaltu obiektu wnioskowania, która Dignāga przedstawił w swoim dziele Pramānasamuccaya: „There are some logicians who think that the object of inference is the predicate (the probandum) [sädhya], which is invariably connected with the probans [hetu]. Others again think it is the connexion that is inferred and neither the subject [paksa] nor the predicate, because they are known from other evidence. But both these views are untenable. If the probans is known to be invariably connected with the probandum the latter is already known at the time the connexion was apprehended. If it is contended that the predicate was not know as related to the subject, well, let then the subject thus qualified be regarded as the probandum. The connextion too cannot be the subject-matter of inference, because it does not contain the two terms, the probans and the propandum in its fold like the subject. Moreover, the relation is not stated as the probandum in the syllogism either by name or through a case-ending. And the probans is not shown to be connected with the relation. Moreover, the relation is tacitly included in the probandum and need not be stated. So it is neither the subject, nor the predicate, nor again the relation that is inferred; but it is 
ślowy przebiega od dymiqcej góry do plonqcej góry, a nie od dymu do ognia. Relacyjność nie jest tylko cechą wewnętrzną przeslanek, taką naturę ma również struktura wnioskowania - przejście od tezy poprzez przeslanki do wniosku.

\section{Zakończenie}

Przeprowadzona analiza pokazuje jak wnioskowanie w buddyzmie jest silnie związane z epistemologią $\mathrm{i}$ wtórne w stosunku do percepcji i od niej zależne. Wnioskujemy na podstawie doświadczonych zmysłami bodźców, które w odpowiednich warunkach stanowia rację stawianej tezy. Istotnym elementem schematu wnioskowania sa przykłady pozytywny i negatywny, majace na celu unaocznienie relacji między racją (hetu) a wlasnością do udowodnienia (sādhya). Zdania je wyrażające zdają sprawę z doświadczenia osoby je wypowiadającej. Ponadto w przypadku budowanych schematów wnioskowania istotnym elementem jest, aby swoją struktura odzwierciedlały one proces myślowy, który wykonuje osoba podczas wnioskowania dokonywanego na poziomie mentalnym. To z kolei wiąże się nieodzownie z pragmatycznym charakterem calej indyjskiej refleksji logicznej. Odwolując się do struktury procesu psychicznego odpowiadającego wnioskowaniu odbywającemu się na poziomie umyslowym, można bylo być pewnym, że w toku dyskusji rozmówca przy prawdziwych przesłankach uzna postawioną tezę. W zwiazku z tym opis i interpretacja indyjskich koncepcji logicznych, roszczace sobie prawo do bycia rzetelnymi, powinny oddawać ich aspekt epistemologiczny. Skupienie się tylko na wyabstrahowaniu z nich pewnych cech formalnych, które wydają się antycypować pewne wspólczesne prawa logiczne, nie jest korzystne dla zachowania oryginalnego ksztaltu indyjskiej refleksji logicznej. W efekcie pokazany zostaje jedynie niewielki fragment calego za-

the subject $[p a k s a]$ as qualified by the predicate $[s \bar{a} d h y a]$, which is inferred on the strength of invariable relation between the probans and the probandum observed elsewhere (sic!)”. (Cyt. za: Mookerjee 1997: 349f.). 
gadnienia, bez szerszego kontekstu, w którym funkcjonuje. Jest to podejście badawcze, które w dużym stopniu ogranicza możliwość dobrego poznania i zrozumienia jednego $z$ aspektów kultury indyjskiej, jakim jest logika.

\section{Bibliografia}

Ajdukiewicz, K. 2003. Kierunki i zagadnienia filozofii. Warszawa: Wydawnictwo Antyk.

Balcerowicz, P. 2003. Historia klasycznej filozofii indyjskiej. Warszawa: Dialog.

Bhatt, S. R., Mehrotra, A. 2000. Buddhist Epistemology. Westport: Greenwood Press.

Bocheński, J. M. 2001. The Indian Variety of Logic. w: J. Ganeri (wyd.) Indian Logic: A Reader. Richmond: Curzon Press 2001. 117-150.

Kania, I. 2007. Muttavali. Wypisy z ksiag starobuddyjskich. Warszawa: Wydawnictwo Aletheia.

Matilal, B. K. 1998. The Character of Logic in India. New York: State University of New York Press.

Mookerjee, S. 1997. Buddhist Philosophy of Universal Flux: An Exposition of the Philosophy of Critical Realism As Expounded by the School of Dignaga. Delhi: Motilal Banarsidass Publishers.

Przybyslawski, A. 2009. Buddyjska filozofia pustki, Wroclaw: Wydawnictwo Uniwersytetu Wroclawskiego.

Russell, B. 2000. ABC teorii względności. Warszawa: Fundacja Aletheia. Śan்karasvâmin, 1995. Nyâya-praveśa. Studia indologiczne vol. 2. Warszawa. 39-87.

Scherbatsky T. 1962. Buddhist Logic. New York: Dover Publication Inc. 